\title{
SOCIALLY RESPONSIBLE REAL ESTATE BROKERAGE IN THE PANDEMIC ERA
}

doi:10.2478/czoto-2021-0034

Date of submission of the article to the Editor: 29/11/2020

Date of acceptance of the article by the Editor: 29/03/2021

Piotr Tomski ${ }^{1}$ - orcid id: 0000-0002-8561-8445

${ }^{1}$ Czestochowa University of Technology, Poland

Abstract: Social responsibility in the real estate brokerage, which is essentially "people's business" may be particularly important while facing the SARS-CoV-2 pandemic and coming down with COVID-19, which is largely the result of interpersonal contact. Thus, the sector seems to be an important link in preventing the spread of infections. The objective of the study is to analyze the adjustment of the real estate sector to new challenges in terms of CSR, related to the coronavirus pandemic. Keywords: real estate market, agent, broker, responsibility, COVID-19,

\section{INTRODUCTION}

The way the society operates or how friendly and green the environment largely depends on economic organizations and specifically on people responsible for business strategies of these companies. In this context, managers' approach to the business run by them is crucial. Corporate Social Responsibility (CSR) is increasingly becoming a part of the strategy of real estate companies. There are many references to CSR, relating to environmental aspects, including green construction or passive building designs. This is often linked to investment and real estate management. An important CSR issue, in terms of real estate, is also, however, real estate brokerage, which, as an economic activity, is the bridge between the investment dimension of the real estate sector and people and organizations using real estate in life and in business. It can be noted that real estate brokerage is a part of a specific CSR chain created by activities in the real estate sector, brokerage and entities buying/renting properties. The involvement of real estate agencies in CSR activities is crucial to ensure CSR continuity and universality around the real estate.

An interest in CSR in the real estate brokerage sector, which is essentially "people's business" may be particularly important while facing the SARS-CoV-2 pandemic and coming down with COVID-19, which is largely the result of interpersonal contact. Thus, the sector seems to be an important link in preventing the spread of infections. A significant number of interpersonal contacts by real estate agents is an activity affecting the possibility of infections. Responsible and ethical behavior of agents in order to prevent COVID-19 may therefore exert a large impact on the reduction in infections in this sector. 
At the same time, it should be pinpointed that social responsibility and business ethics significantly affect the management system, thus improving its efficiency, and have an impact on better economic results achieved by enterprises (Kulawczuk and Poszewiecki, 2007). Competition in the real estate market forces entrepreneurs to seek more effective tools to gain a competitive advantage on competitors. Nowadays, it is often pinpointed that in order to maintain a good image, enterprises ought to include environmental protection and social responsibility in their strategies, both in a short and long term. Socially and environmentally friendly business activities have grown in importance thus becoming a new source of competitive advantage (Wieteska-Rosiak, 2013).

Considering the above, the paper objective is to analyze the adjustment of the real estate sector to new challenges in terms of CSR, related to the coronavirus pandemic.

\section{RESPONSIBLE BUSINESS CONDUCT IN REAL ESTATE BROKERAGE FACING COVID-19}

The coronavirus disease (COVID-19) is a human social and economic crisis that has attacked the core of human existence. It continues to spread uncontrollably around the world (Verma and Gustafsson, 2020). Its impact on the global economy is likely to be unprecedented since the 1930s Great Depression (Euronews, 2020). It is causing a dramatic, negative changes in macroeconomic measures. The real estate market, as for other productive and commercial sectors, in the medium-long term, will not tend to move independently from those changes (Del Giudice et al., 2020). The impact of the crisis on real estate companies is ranked "High" by International Labor Organization (ILO Monitor, 2020). Thus, the pandemic may represent one of the most significant environmental changes in the modern marketing history, which could have a profound impact on CSR, consumer ethics, and basic marketing philosophy ( $\mathrm{He}$ and Harris, 2020). The pandemic has been pushing businesses to operate in newer and more resilient ways (Ivanov, 2020). COVID-19 is affecting all service sectors (Addo, 2020). Service workers are working in grim and testing working environments, exposed to the virus with no choice but to work (Frazer et al., 2020). The pandemic in Poland (PARP, 2020) has forced to take a number of radical steps which severely affected the country's economy.

The Polish Agency for Enterprise Development indicates exemplary operations in terms of preventing the spread of the SARS-CoV-2 virus. These operations include a few areas (PARP, 2020): customers (ensuring their safety), equipment (material and financial support for health care institutions), employees (ensuring safety), counteracting the effects of the crisis (consulting, loans, credits), support for the elderly and other needy and education and systemic support in the field of anti-crisis prevention.

In the face of COVID-19, it is necessary to implement the concept of responsible business conduct (RBC) and further inclusion of RBC principles and tools in the core of business activities. OECD (2020) pays particular attention to the inclusion of CSR in response to COVID-19. In the case of enterprises, the RBC approach can be often implemented using scarce resources and, in addition to social ones, they may bring direct economic benefits.

Among the approaches in the field of RBC indicated by OECD (2020), which can be simultaneously perceived as particularly important in terms of service activities, management of environmental, health and safety issues should be identified in 
a manner that counteracts short-term risks by avoiding accidents and protecting workers and consumers.

New operating rules, including social distancing, are being established for the safety of people with the warning that failure to take a precautionary action can lead to the severity of the situation and then people will be in lockdown once more (Sarwar, 2020). Companies seeking to engage with CSR need their employees to endorse the concept, in order to implement them the way it is required (Pushkala, 2016). As for all business sectors, CSR is a vital and core strategy that needs to be of central concern to the real estate sector. In the current pandemic, the real estate sector, to remain relevant, can no longer ignore the call to be proactive in CSR programs (Thomass and Potluri, 2020).

According to Ojo and Araloyin (2013), a socially responsible real estate agency can be defined as a new way of practicing agency that looks for solutions to every deal in such a way that every party involved benefits from the process. It can also be defined as voluntary actions by the estate agents, homeowners, home buyers, and renters that go beyond minimum legal requirements to increase the positive and reduce the adverse social and environmental effects of real estate agency transactions. It means providing services that give excellent return for their money and a high degree of ethical, social, and environmental comfort. Facing the pandemic, real estate agencies want to offer stability and comfort knowing that real estate needs are still being met in a safe and responsible manner.

\section{MATERIALS AND METHODS}

The objective of the study is to analyze the adjustment of the real estate sector to new challenges in terms of CSR, related to the coronavirus pandemic.

The presented research problem has been formulated as follows: In what way does the real estate brokerage sector adjust the activities of its agents and the entities involved in the real estate market services to the conditions of the coronavirus pandemic?

Two qualitative research methods have been employed: the interview and (Gudkova, 2012; Qu and Dumay, 2011) the analysis of the desk research (Łuczewski and Bednarz-Łuczewska, 2012; Bowen, 2009). The interview conducted with 20 agents from Poland was non-standardized and unstructured (free). This type of the exploration interview is mostly applied in qualitative research. The question put in the interview related to real actions associated with safety during the pandemic and the degree of their formalization. The results of the interview directed further research to the analysis of the documentation - formal material, i.e., the COVID-19 Safety Charter campaign.

\section{RESEARCH RESULTS}

\subsection{The cooperative concept of responsible business in real estate brokerage in Poland}

The interviews with the real estate agents lead to the conclusion that work in the real estate sector is primarily about interpersonal relations. Although initial lockdown and subsequent reduction in contacts caused that most presentations and discussions have been transferred to the Internet, the agents pinpoint that practically there is no opportunity to sell or rent real estate exclusively online. Eventually, every potential 
customer wants to see the real estate for real. In these circumstances, an urgent need has emerged to define the principles of conduct in the event of the existing pandemic - so that real estate agents and customers could feel safe and the behavior of all stakeholders would not be intuitive or random but governed by thoughtful recommendations.

The demonstration of responsible business conduct in real estate brokerage is the Covid19 Safety Charter created in Poland, based on the procedures and recommendations of the Polish Government and the Chief Sanitary Inspector. The Charter is to ensure maximum safety for both customers and employees of the companies/organizations being the signatories to the Charter. The key principles, determining actions in both public and private space the Charter is based on are social distancing, disinfection and covering the mouth and nose. It should be pinpointed that it is the first and only initiative of this type in Poland. It was created on the initiative of social organizations and commercial entities. It is a pro-social nonprofit project.

To increase security awareness in business contacts between agents and other entities involved in transactions, all the activities related to the behavior during contacts with customers and entities providing services in the real estate market have been collected and described under the Charter. In business practice, they are transferred to individual stakeholders, adequately to the needs resulting from the stage of operation in the real estate sale/purchase process.

The creators and participants of the Charter relate their initiative to the assumption that joint actions will allow for effective work and ensure a sense of security. For the success of the Charter, it is crucial to promote and use it extensively in business. A particular attention is paid to labelling (the Charter logotype), transparency (information on the access to the Charter is published on the websites of both the project itself and real estate agencies/agents) and involvement (each signatory is involved in its promotion among both customers and other professionals of the real estate market).

Under the initiative, the procedures - recommendations have been prepared, implemented voluntarily by the organizations involved. These actions are suggested as being aimed at the welfare of all stakeholders. In each document compiled, it is pinpointed that the recommendations by the Government and the Chief Sanitary Inspector play a superior role over the procedures prepared. Signing the charter guarantees that its signatories are aware, responsible and prepared for new challenges.

To facilitate the application of the procedures, the posters and information have been compiled to be sent to customers or cooperating companies. Among them, the following slogans can be found: "disinfect your hands", "keep the distance", "the real estate ready for the presentation". All of the materials for the Charter are aesthetic, friendly and positive.

Due to the fact that the Charter is a common project of the entire real estate market, the originators and organizers of the action suggest cooperation with those willing and announce readiness to accept any ideas or tips on how to improve its operation and promote it. The activities under the Charter are additionally reflected on Facebook in the form of the public group founded in October 2020, with 70 members as on the date of the research (1.12.2020). 


\subsection{COVID-19 Security Charter procedures as the demonstration of the sector's concern for all stakeholders}

The procedures have been prepared following the specificity of work of real estate agents and agencies. Each of the procedures shall bear the information: "Our company is the signatory to the COVID-19 Security Charter for the real estate market which is to ensure maximum safety to both the customers and employees of our company. Therefore, we present the procedures to you". All the procedures, except for detailed ones, adequate to the specificity of the agent's operation, contain basic tips on social distancing, covering the mouth and nose, disinfecting hands and ventilating rooms (before and after visits).

The first procedure relates to the expected customer behavior. It is suggested that the customer should reschedule their appointment if they live with someone with the symptoms of COVID-19 or are in close contact with someone with the confirmed COVID-19 infection or has returned to Poland from another country in the last 14 days. Only two people are invited to the office at the same time.

The second procedure relates to the preparation of the real estate for customer visit. They should be arranged in advance, especially if the property is inhabited. If possible, the real estate should be presented without the owners' participation. The owner is notified about the presentation and the number of people present shall be kept to a minimum. The people in the property shall be instructed on the rules of conduct by the agent. The customer visiting the property shall avoid touching the objects inside. The door is left ajar so that the customer does not have to touch the handle. It would be advisable for the agent to be the person presenting the real estate.

The third procedure relates to the process of accepting the real estate for sale. It contains three areas: meeting property owners, signing documents and preparing the real estate for sale. Under this procedure it is recommended to minimize the number of direct meetings. All documents and prints necessary to conclude the cooperation should be available in an electronic form. When completing the documentation, it is recommended to use the ePUAP electronic platform where possible. After activities in the customer's property, such as a photo session, it is necessary to ventilate the space and disinfect the objects touched. It is recommended to use the objects in the property for the photo session.

The fourth procedure contains the tips for real property owners given before the presentation. Another, the fifth procedure relates to the presentation of the property, according to which presentations are individual, in a group of a maximum of 2 people. Before arranging the presentation, contact details are sent via e-mail or a short text message. RODO information and address collection forms are sent electronically if possible. The property information sheet is sent via e-mail so that no document signature process takes place during the meeting. Before the presentation the property owner receives the comprehensive information on security principles and the Charter.

Another, the sixth procedure relates to home staging activities. It is recommended for the real estate preparation procedure to be individualized and adjusted to the situation of the property. If the real estate is uninhabited, traditional (pre-pandemic) practices can be applied, however, the procedure suggests that, before entering the property, it is worth disinfecting your hands, ventilating the property, maintaining permanent access of fresh air, making the most of the equipment available in the property and 
using external decorative items or equipment only if necessary. In a situation where the property is inhabited, it is ideal for the owners not to be present in the property during home staging. People staying in ought to keep their distance.

The seventh procedure relates to the principles of work at the office. The tips suggest not coming to the office with the symptoms of any infections and the need to remotely inform on possible poor health condition (superior/manager) and the possibility of remote work. The attention is drawn to the need to obey basic safety rules (distance, covering the face, disinfection) and the need to enable the office management to comply with them. It is suggested to use disposable towels, regularly disinfect the workstation, leave outer garments in designated areas, use a social room in accordance with safety rules.

Due to the fact that knowledge and awareness are basic factors enabling the minimization of risk of infection, one of the basic principles of the Charter is to conduct training on the principles of the COVID19 Security Charter. The eighth procedure applies to this area. It includes introducing the team to the implemented procedures of the Charter, obtaining a written acknowledgement of compliance with the procedures, sending information via e-mail to each employee/web address with procedures/ all the procedures and introducing e-mail footer "We are the signatories of the Security Charter - You are safe with us!".

Another procedure relates to "Open House". During "Open House" owners should not be present in the property. Presentations take place individually, in a group of a maximum of 2-3 people. The door in the property is left ajar. Visitors should avoid touching objects in the property. The presentation (opening wardrobes, equipment) is made by the organizer of the meeting. After each presentation, the disinfection of the places touched or exposed to contact with visitors shall be carried out. Customers are served only drinks or snacks in disposable packages. Customer register their presence in the visitor register using disinfected pens or their own.

The tenth procedure is where the employee is diagnosed with or suspected of being infected with COVID-19. If the worker observes the symptoms that may indicate a respiratory infection in themselves or their coworker, they should be isolated. In the event of disturbing symptoms suggesting an infection, the employee shall cease to perform their professional duties immediately, including in particular meetings with customers. The suspected infection is reported to the person indicated by the agent who will ensure safe transport to their home, hospital or clinic. In these circumstances, the other employees shall leave the office, especially, if it is impossible to isolate the worker with the suspected infection. It is recommended to disinfect the hands, the shower immediately after arriving home and washing all the clothes or putting them aside and not using for a minimum of 2 days. The area where the worker with the infection has moved should be thoroughly cleaned and touch surfaces ought to be disinfected (handles, handrails etc.) The employee suspected of COVID-19 is obliged to contact a doctor or a public health inspection station (Sanepid). The worker shall not resume their duties until the situation is clarified or the COVID-19 test is negative. The eleventh procedure relates to conducting professional training. Training takes place in the stationary, hybrid or online form. Applications for training are sent electronically as well as the settlement of participation costs. The training provider shall keep the register of training participants and attendance at classes. The organizer provides the rooms to meet the requirements currently in force. Participants fill in a health survey before training begins. Course materials are delivered 
electronically. If materials are provided in the paper form, each participant shall receive an individual package. Training time is optimized to ensure breaks and ventilation. Training participants use their own stationary. Catering is delivered in disposable packaging if possible.

The twelfth procedure relates to signing documents. All the documents and prints necessary to conclude the cooperation should be available in an electronic form. When completing the documentation, it is recommended to use the ePUAP electronic platform where possible. With the activities performed personally the principles of social distancing are followed and personal protective measures are applied. Before signing documents, hands are disinfected. Documents are signed using pens provided by the agent or the ones belonging to each of the parties.

The thirteenth procedure describes the principles of behavior towards the customer in the office. Meetings with customers take place after prior arrangement of the date and time. Before the meeting the customer should be informed via e-mail or on the phone on the rules for visiting the office. If the office keeps the record of visits, the customer records their presence using disinfected pens or their own. The meeting takes place in a room where it is possible to keep a safe distance. The meeting should be held with a minimum number of people. If there is an opportunity, the customer is served drinks or snacks in disposable packaging. The meeting should not last longer than the situation requires.

The fourteenth procedure concerns the relationship with the notary. It should be seen as particularly important since the notary, just like the agent, contacts many people and, at the time of signing a notarial deed, several people representing the parties to the transaction usually gather in one room. Documents and data necessary for the preparation of the act are submitted to the notary electronically by the parties to the transaction and they are verified in the course of signing. Initial verification and acceptance of all content takes place in an electronic form. A minimum, necessary number of people shall take part in the meeting related to signing a notarial deed. The time of reading and signing the act is minimized. When signing documents every person receives a separate pen or uses their own. Stationaries are disinfected. Payments due at notary offices (including taxes and court fees) are made in a noncash form. The notary shall provide documents to the parties in holders. It is recommended to put the documents aside at home for a period of about two weeks. The procedure should be forwarded to both the customer and the notary.

\section{CONCLUSION}

The coronavirus pandemic has an impact on the real estate industry. All the steps, from managing brokerage operations, to marketing listings, and closing transactions, requires agents to adapt to these extraordinary circumstances. The unprecedented pandemic times affect agents' ability to conduct their businesses, and ability to navigate these uncertain times is paramount. Any guidance is definitely to help agents to respond to the coronavirus's impact on the real estate industry.

The introduction of the Security Charter can be undoubtedly seen as the manifestation of responsibility of real estate agencies facing the pandemic. The analysis of individual procedures leads to the conclusion that the tips seem to be obvious. Pinpointing them and paying attention to individual stages of operations in the process of attracting customers to the finalization of the transaction increases the probability of responsible behavior and, at the same time, reduction in the spread of 
the virus. The more companies, organizations and other entities operating in the market will take part in this action and the more the logos and materials linked to the action will be used the better results it will bring and the more it will reach the awareness of stakeholders.

An interest the Charter has been accepted with is the evidence of the fact that specialists operating in the real estate market are aware that it is crucial to mobilize the entire community. As a result, more and more companies will become the signatories of the Charter. The COVID19 Security Charter and the companies taking part in the program are distinguished by the characteristic logotype created for the purposes of this initiative. In the opinion of the originators, as a sign of the times, it has an opportunity to fit into the landscape of the real estate market.

The operations of enterprises under the Charter, treated as a part of CSR management, being a certain pattern of conduct introduced into their structure, should be evaluated in subsequent steps and their effects verified.

This study has some constraints. The presented set of principles is recommended only in one country - in Poland. When making an attempt to draft future research, it should be stated that it would be justified to conduct international analyses, showing the differences in the approach to protective measures and, at the same time, enabling the development of the set of universal recommendations, adequate to all the investigated countries. Such an analysis would also allow for the identification of agents' approach to security depending on the country and possibly the continent.

\section{REFERENCES}

Addo P.C., Jiaming F., Kulbo N.B., Liangqiang L. 2020. COVID-19: Fear appeal favoring purchase behavior towards personal protective equipment, Service Industries Journal, 40 (7-8), 471-490, DOI: 10.1080/02642069.2020.1751823

Bowen, G.A. 2009. Document analysis as a qualitative research method, Qualitative research journal, 9 (2), 27-40, DOI: 10.3316/QRJ0902027

Del Giudice, V., De Paola, P., Del Giudice, F. P. 2020. Covid-19 infects real estate markets: Short and mid-run effects on housing prices in Campania region (Italy). Social Sciences, 9 (7), 114, DOI:10.3390/socsci9070114

Euronews (2020), COVID-19: World economy in 2020 to suffer worst year since 1930s Great Depression, says IMF, https://www.euronews.com/2020/04/14/watchlive-international-monetary-fund-gives-world-economic-outlook-briefing-on-covid-19 (6.05.2020)

Facebook Public Group „Karta Bezpieczeństwa COVID-19” https://www.facebook.com/groups/kartabezpieczestwacovid19/about (1.12.2020)

Frazer, L., Merrilees, B., Nathan, G., Thaichon, P. 2020. Creating Effective Franchising Relationships: Challenges of Managing Mature Franchisees. In Entrepreneurship and Organizational Change, Springer, Cham, 135-148, DOI: 10.1007/978-3-030-35415-2_7

Gudkova, S., 2012. Wywiad w badaniach jakościowych, in: Jemielniak, D. (ed.), Badania jakościowe, tom. 2, Wydawnictwo Naukowe PWN, Warszawa, 111-130.

He, H., Harris, L. 2020. The impact of Covid-19 pandemic on corporate social responsibility and marketing philosophy, Journal of business research, 116, 176182. DOI: $10.1016 /$ j.jbusres.2020.05.030

ILO Monitor, 2020. COVID-19 and the world of work. Third edition Updated estimates and analysis, Labour Organization, 29 April 2020, 6, 
http://oit.org/wcmsp5/groups/public/---dgreports/---

dcomm/documents/briefingnote/wcms_743146.pdf (2.12.2020)

Ivanov, D. 2020, Predicting the impacts of epidemic outbreaks on global supply chains: A simulation-based analysis on the coronavirus outbreak (COVID19/SARS-CoV-2) case, Transportation Research Part E: Logistics and Transportation Review, 136, 10192.

Kulawczuk, P., Poszewiecki, A., (eds.), 2007. Analiza korzyści ekonomicznych ze stosowania zasad społecznej odpowiedzialności biznesu (CSR) 1 w polskich przedsiębiorstwach, Wpływ społecznej odpowiedzialności biznesu i etyki biznesu na zarządzanieprzedsiębiorstwami, Warszawa.

Łuczewski, M., Bednarz-Łuczewska, P. 2012. Analiza dokumentów zastanych, in: Jemielniak, D. (ed.), Badania jakościowe, tom. 2, Wydawnictwo Naukowe PWN, Warszawa, 163-188.

Ojo, O., Araloyin, O.F. 2013. Real Estate Agency and CSR in: Idowu, S.O., Capaldi N., Zu, L., Gupta, A.D. (eds.) Encyclopedia of Corporate Social Responsibility. Springer, Berlin, Heidelberg. Retrieved July 24, 2020, https://link.springer.com/referenceworkentry/10.1007\%2F978- 3-642-280368_684\#howtocite

PARP 2020, Odpowiedzialny biznes w dobie COVID-19, https://www.gov.pl/web/fundusze-regiony/polskie-przedsiebiorstwa-walcza-z-covid19 (10.11.2020)

Pushkala, M. 2016. Corporate Social Responsibility initiatives and employee perspectives in UAE, Polish Journal of Management Studies, 14 (2), 172-181, DOI: 10.17512/pjms.2016.14.2.16

Qu, S.Q., Dumay, J. 2011. The qualitative research interview. Qualitative research in accounting \& management, Qualitative Research in Accounting \& Management, 8 (3), 238-264, DOI 10.1108/11766091111162070

Sarwar, F., Panatik, S. A., Sarwar, F. 2020. Psychology of Preventive Behavior for COVID-19 outbreak, Journal of Research in Psychology, 2 (1), 1-3.

Tackling coronavirus (COVID-19). Contributing to a global effort, OECD, 2020, https://mneguidelines.oecd.org/

Thomass, S.S., Potluri, R.M. 2020. An Exploratory Research on the Implementation of Corporate Social Responsibility (CSR) in the Real Estate Sector of UAE: A Dyadic Perspective, The Journal of Distribution Science, 18 (10), 101-110, DOI: 10.15722/jds.18.10.202010.101

Verma, S., Gustafsson, A. 2020. Investigating the emerging COVID-19 research trends in the field of business and management: $A$ bibliometric analysis approach. Journal of Business Research, 118, 253-261, DOI: 10.1016/j.jbusres.2020.06.057

Wieteska-Rosiak, B., 2013. Zrównoważony biznes na przykładzie zielonych inwestycji na rynku nieruchomości, Ekonomia i Środowisko, 1 (44). 